\title{
KUALITAS KEBERSIHAN LINGKUNGAN SEBAGAI PENUNJANG DAYA TARIK WISATA PANTAI SANUR KAJA
}

\author{
Sara Violinaa,1, Ida Bagus Suryawan ${ }^{\mathrm{a}, 2}$ \\ ${ }^{1}$ saraviolina07@gmail.com,2inigusmail@yahoo.com
}

a Program Studi S1 Destinasi Pariwisata, Fakultas Pariwisata,Universitas Udayana, Jl. Dr. R. Goris, Denpasar, Bali 80232 Indonesia

\begin{abstract}
Northern Sanur Beach (Sanur Kaja Beach) consisting of Matahari Terbit Beach and the main Sanur Beach is a polular tourist destination on the island of Bali. Its strategic location, famous history, public and additional facilities, makes Sanur a demanding location for tourists. But one important role for such tourist destination is the cleanliness of the beach itself, providing comfort to travellers. A direct observational study and a descriptive crosssectional study with randomized survey of 100 travellers (50 domestic and 50 international) regarding the cleanliness of Northern Sanur beach. Through the survey we gathered traveller's evaluation on current sanitation of public facility (toilet, parking, and resting), additional facilities (restaurant, gift shop, and street vendors), and sanitary facility (rubbish bins) condition in Northern Sanur beach giving a score of very clean, moderate, or poor. Through direct observational we looked at physical objects around the environement such as its geography and facilities available in Northern Sanur beach collected through interviews from local informans. Respondents showed an overall positive response of "moderate" 25 of respondents or (50\%) of domestics, and 32 respondents or (64\%) foreigners regarding sanitation quality of Northern Sanur beach. Public facilities as well as additional facilities are generally considered to be moderately clean by the total respondents. But traveller's opinion suggested the "poor" availability of rubbish bins 25 of respondent or (50\%) domestics and 23of respondents or (46\%) foreigners. Public facilities of four public toilets, two parking area, rubbish bins, are available for travellers and taken care by local employees assigned by the head of village. As travellers states Northern Sanur to be moderately clean, other results that are considered poor or below expectation regarding specific public facilities should be taken care of to provide a better tourist attraction. Cleanliness is a tourist attraction itself, therefore keeping clean it is important for the sustainability of tourism.
\end{abstract}

Keywords: Environmental Sanitation, Public and Additional Facilities, Travellers

\section{PENDAHULUAN}

Pantai Sanur Kaja (Kaja yang artinya utara) terkenal dengan keindahan Pantainya yang ramai dikunjungi ribuan wisatawan setiap harinya. Tempatnya yang merupakan perbatasan antara Pantai pasir hitam dan pantai pasir putih memiliki daya tarik tersendiri serta nilai sejarah tinggi. Kelengkapan berwisata di Pantai Sanur Kaja ditunjang dengan sarana umum, berbagai restoran wisata kuliner, hotel, dan tempat perbelanjaan. Sebagai daya tarik wisata yang sudah memiliki potensi baik sudah seharusnya Pantai Sanur Kaja memiliki suatu penunjang khususnya pada sarana-sarana penunjang kebersihan. Suatu sarana yang nyaman dan bersih sangat berperan dalam menarik wisatawan, oleh karena itu diperlukan kualitas kebersihan dan kenyaman yang baik bagi wisatawan yang datang berkunjung.

Kualitas kebersihan yang merupakan kondisi nyaman secara umum bagi wisatawan yang diciptakan oleh pegelolaan daerah wisata itu sendiri. Baik wisatawan, penduduk lokal, dan pengelola sarana umum atau pribadi turut berperan dalam menjaga kualitas kebersihan Pantai Sanur Kaja. Dengan meningkatnya jumlah wisatawan ke Pantai sanur, maka juga berdampak pada peningkatann berbagai produk dan sarana untuk memenuhi kebutuhan wisatawan. Sehingga jumlah sampah dan limbah pun meningkat dari wisatawan ataupun sarana penunjang, dan berdampak pula pada kualitas kebersihan Pantai Sanur Kaja. Sehingga fasilitas saling berhubungan erat dengan pengunjung dan pada kebersihan tempat wisata itu sendiri. Tujuanya penelitian ini dilakukan adalah untuk menganalisa lebih lanjut seberapa baik kualitas kebersihan pada Pantai Sanur Kaja Banyak fenomena dimana wisatawan asing sangat tidak nyaman dengan kebersihan sarana penunjang umum seperti toilet, tempat pemandian umum, dan tempat sampah yang tidak memadai sehingga mereka meragukan destinasi wisata tersebut. Beberapa toilet umum di daerah wisata pun masih belum 
memadai perawatannya sehingga kurang nyaman digunakan. Terlebih lagi, sanitasi yang buruk dapat menyebabkan penyakit oleh karena itu, kualitas kebersihan yang kurang seperti pada tempat makan di jalanan ataupun lingkungann yang kotor merupakan risiko kesehatan bagi wisatawan yang mengunjunginya.

Kualitas kebersihan sangat

berperanpenting dalam menciptakan suasana lingkungan daya tarik wisata yang nyaman dan dapat dinikmati wisatawan atau pengunjung untuk dapat menilai sejauh mana kualitas kebersihan ,Maka diperlukan suatu penilaian dan penelitian yang konstan dan terus menerus mengenai kualitas kebersihan di Pantai Sanur Kaja untuk pengembangan daya tarik wisata dan memberikan citra positif bagi wisatawan yang datang mengunjunginya.

\section{METODE}

Sesuai tujuan penelitian untuk mengetahui kualitas kebersihan Pantai dan sarana di Pantai Sanur Kaja saat ini, maka digunkanlah metode observasi langsung dan wawancara, serta survei langsung kepada wisatawan.

Melalui observasi langsung dan wawancara kita mengumpulkan data mengenai jumlah sarana penunjang pariwisata di Pantai Sanur Kaja. Sarana yang dimaksud adalah sarana umum yang termasuk toilet, tempat parkir, dan tempat beristirahat terbuka; sarana tambahan yang termasuk restoran, toko souvenir, dan pedagang jalanan; dan sarana kebersihan yakni tempat sampah. Wawancara dilakukan pula pada pedagang, pemilik sarana, perangkat desa, dan pegelola daerah wisata Pantai Sanur Kaja untuk mendapatkan informasi mengenai pengelolaan kebersihan Pantai Sanur Kaja.

Pengambilan data ini menggunakan kuisioner yang diisi oleh wisatawan. Survei dilakukan menggunkan metode pengambilan sampel secara acak (randomized data collection) hingga diperoleh 100 wisatawan (50 domestik dan 50 internasional) untuk mengisi kuisioner. Survei pada wisatwan domestik dan internasional dilakukan menggunakan kuisioner dengan variabel yakni; sarana umum, sarana tambahan, sarana kebersihan, dan penilaian kebersihan Pantai secara keseluruhan, yang dinilai oleh responden dengan nilai; baik, cukup, atau kurang. studi ini dilakukan selama 3 minggu pada bulan November 2014.

\section{HASIL DAN PEMBAHASAN}

Melalui pengamatan langsung di Pantai Sanur, berbagai sarana penunjang pariwisata dapat ditemui. Pada jalan utama Pantai Sanur, yakni Jalan Hangtuah, dapat ditemukan berbagai restoran, toko-toko, sebuah pura dan masjid, dan berbagai hotel. Terletak disebelah utara di Jalan Matahari Terbit dapat ditemukan toko-toko makanan penduduk lokal, tempat peristirahatan terbuka, dan parkir yang luas. Hasil observasi menunjukan terdapat hampir 20 tempat sampah, 6 tempat peristirahatan terbuka, dan 4 toilet yang tersedia sepanjang Pantai Sanur Kaja.

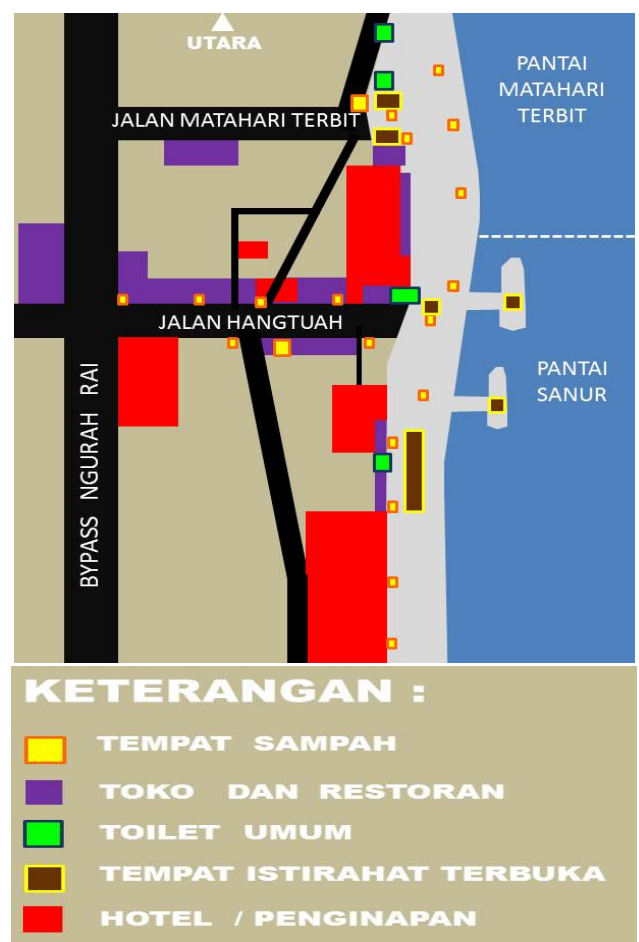

Gambar 1. Peta wilayah Pantai Sanur Kaja dan fasilitas yang tersedia.

Melalui wawancara langsung kepada kepala Desa Sanur Kaja, Ida Bagus Paramartha, diketahui bahwa pengelolaan sarana dan prasarana Pantai Sanur Kaja dilakukan di masing-masing Pantai, yakni Pantai Matahari Terbit dan Pantai Sanur. Ada sekitar lima warga setempat yang bertugas untuk membersihkan areal Pantai Sanur Kaja dan mereka digaji perbulannya oleh pengurus desa. Pengelolaan sampah pula telah diatur oleh desa yang 
bekerjasama dengan dinas kebersihan pusat dengan adanya satu pusat pembuangan sampah di Pantai Matahari terbit dan pemungutan sampah pinggir jalan di areal Pantai Sanur yang diambil setiap pagi. Lahan parkir yang luas disediakan dan dikelola oleh para tukang parkir yang merupakan warga lokal dan dipertanggungjawabkan ke kepala desa. Adapun empat toilet umum ataupun toilet pribadi yang disediakan dan para wisatawan yang menggunakannya dipunggut biaya untuk pengelolaan kebersihan dan perawatan toilet tersebut yang berkelanjutan. Limbah dari sarana umum tersebut dibuang melalui sistem limbah umum yang telah ditentukan oleh pemerintah. Para pedagang tetap maupun keliling, pemilik toko souvenir, dan restoran juga turut menjaga kebersihan Pantai Sanur dengan mengatur

pembuangan sampah masing-masing sesuai waktu yang diberikan. Setiap minggunya pula dilakukan gotong-royong pembersihan areal pantai di sekitar tempat mereka berjualan.

Tabel 1. Data Demografik Wisatawan Domestik Dan Internasional Dalam Survei.

\begin{tabular}{|c|c|c|c|}
\hline \multicolumn{2}{|c|}{ Wisatawan } & \multicolumn{2}{c|}{ Wisatawan } \\
Domestik $(\mathrm{n}=50)$ & \multicolumn{2}{c|}{ Internasional $(\mathrm{n}=50)$} \\
\hline Sex: & & Sex: & \\
Pria & $29(58 \%)$ & Pria & $24(48 \%$ \\
Wanita & $21(42 \%)$ & Wanita & $26(52 \%)$ \\
Umur: & & Umur: & \\
Minimum & 18 & Minimum & 25 \\
Maximum & 42 & Maximum & 67 \\
Rata-Rata & 27,52 & Rata-Rata & 43,34 \\
Asal: & & Asal: & \\
Bali & $27(54 \%)$ & Amerika & $4(8 \%)$ \\
Jawa & $10(20 \%)$ & Asia & $20(40 \%$ \\
Kalimanta & $2(4 \%)$ & Australia & $13(26 \%$ \\
NTB/NTT & $6(12 \%)$ & Eropa & $13(26 \%$ \\
Sulawesi & $3(6 \%)$ & & \\
Sumatera & $2(4 \%)$ & & \\
\hline
\end{tabular}

Sumber: Hasil Penelitian

Tabel 2. Hasil Penilaian 50 Wisatawan Domestik Terhadap Variabel Penelitian.

\begin{tabular}{|c|c|c|c|c|}
\hline & ڤ્ּ & 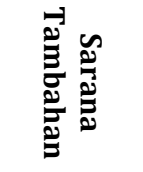 & 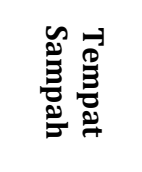 & 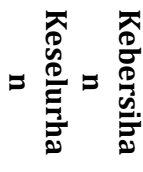 \\
\hline Kurang & $17(34 \%)$ & $\begin{array}{c}3 \\
(6 \%) \\
\end{array}$ & $23(46 \%)$ & $\begin{array}{c}4 \\
(8 \%) \\
\end{array}$ \\
\hline Cukup & $21(42 \%)$ & $35(70 \%)$ & $24(48 \%)$ & $32(64 \%)$ \\
\hline Baik & $12(24 \%)$ & $12(24 \%)$ & $\begin{array}{c}3 \\
(6 \%)\end{array}$ & $14(28 \%)$ \\
\hline
\end{tabular}

Sumber: Hasil Penelitian 


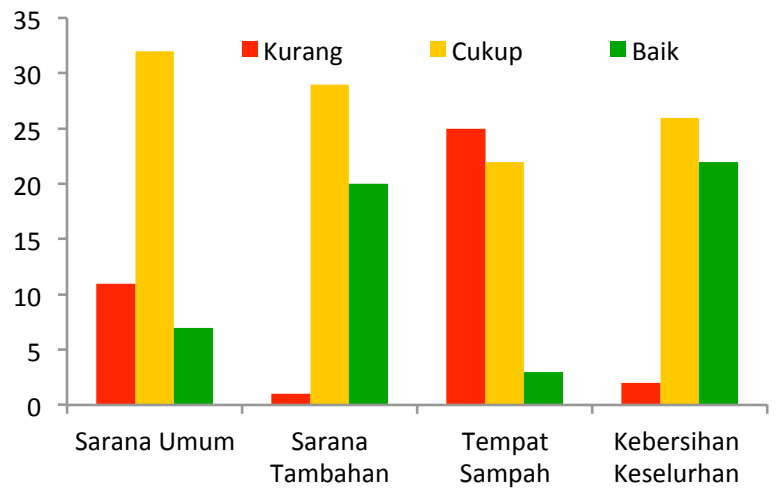

Gambar 2. Grafik hasil penilaian 50 wisatawan domestik terhadap variabel penelitian

Tabel 3. Hasil penilaian 50 wisatawan internasional terhadap variabel penelitian.

\begin{tabular}{|c|c|c|c|c|}
\hline & 옳 & 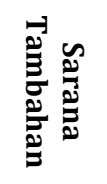 & 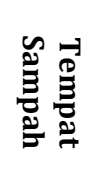 & 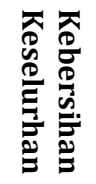 \\
\hline Kurang & $11(22 \%)$ & $\begin{array}{c}1 \\
(2 \%)\end{array}$ & $\begin{array}{c}25 \\
(50 \%) \\
\end{array}$ & $\begin{array}{c}2 \\
(4 \%)\end{array}$ \\
\hline Cukup & $32(64 \%)$ & $\begin{array}{c}29 \\
(58 \%) \\
\end{array}$ & $\begin{array}{c}22 \\
(44 \%) \\
\end{array}$ & $\begin{array}{c}26 \\
(52 \%) \\
\end{array}$ \\
\hline Baik & $\begin{array}{c}7 \\
(14 \%) \\
\end{array}$ & $\begin{array}{c}20 \\
(40 \%) \\
\end{array}$ & $\begin{array}{c}3 \\
(6 \%) \\
\end{array}$ & $\begin{array}{c}22 \\
(44 \%) \\
\end{array}$ \\
\hline
\end{tabular}

Sumber: Hasil Penelitian

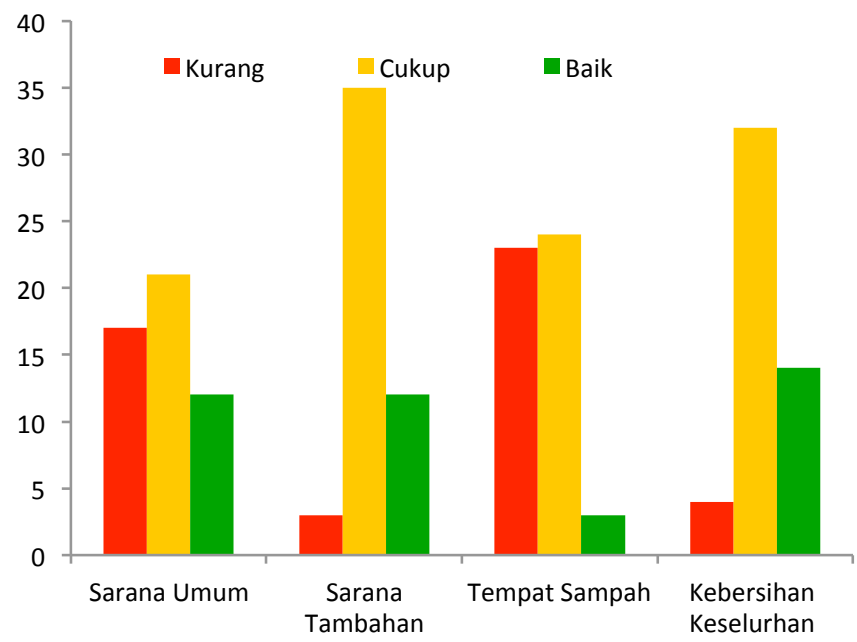

Gambar 3. Grafik hasil penilaian 50 wisatawan internasional terhadap variabel penelitian

Hasil pengisian kuisioner dari 100 responden (50 domestik dan 50 internasional) memberikan hasil pada variabel yang diteliti. Wisatawan domestik (50 orang) terdiri dari 29 orang pria atau $(58 \%)$ dan 21 orang atau setara
(42\%) wanita yang memiliki umur rata-rata 27,52 tahun dengan sebagian besar wisatawan domestik berasal dari Jawa dan Bali. Sedangkan wisatawan international (50 orang) terdiri dari 24 (48\%) pria dan 26 (52\%) wanita yang 
memiliki umur rata-rata 43,34 tahun dengan sebagian besar wisatawan domestik berasal dari Asia.

Hasil menunjukan bahwa wisatawan domestik menilai sarana umum cukup bersih yaitu 32 orang responden setara (64\%). Sarana tambahan dianggap cukup bersih oleh 29 orang responden atau setara (58\%) wisatawan domestik. Namun sebagian besar 25orang wisatawan atau setara (50\%) menganggap masih kurangnya sarana tempat sampah yang ada di Pantai Sanur Kaja. Secara keseluruhan kebersihan dan sanitasi Pantai Sanur Kaja dianggap sudah cukup bersih oleh sebagian besar wisatawan domestik yaitu sebanyak 26 orang responden atau setara (52\%).

Wisatawan mancanegara (50 orang) memberikan hasil yang mengganggap sarana umum yang ada sudah cukup bersih yaitu sebanyak 21 responden atau setara (42\%). Sarana tambahan menunjukan wisatawan mancanegara sebagian besar memberikan hasil cukup bersih yaitu 35 responden atau setara (70\%).Ketersediaan tempat sampah sudah dianggap cukup yaitu 24atau setara (48\%) namun beberapa wisatawan masih mengganggap ketersediaannya masih kurang sebanyak 43 responden (46\%). Secara keseluruhan sebagian besar wisatawan internasional mengganggap kebersihan Pantai Sanur Kaja cukup bersih sebanyak 32 responden atau setara dengan (64\%).

Fenomena yang dihadapi pada daya tarik wisata Pantai Sanur Kaja adalah saat ini kepadatan pengunjung atau wisatawan yang datang tidak sesuai dengan ketersedian sarana kebersihan dan sarana sanitasi yang ada,sehingga adanya permasalahan dimana sampah yang dihasilkan dari kegiatan pengunjung atau wisatawan tidak dapat dikelola dengan maksimal yang dikarenakan kurangnya kesadaran para pngunjung atau wisatawan, serta minim sarana yang tersedia. Hal ini tentu saja sangat berdampak buruk pada citra daya tarik Pantai Sanur Kaja yang jika dibiarkan daya tarik ini akan semakin ditinggalkan karena kurang baiknya pengelolaan kebersihan di daya tarik tersebut. Kualitas kebersihan Pantai Sanur Kaja memiliki berbagai kekuatan, kelemahan, kesempatan, dan Ancaman sebagai suatu daya tarik wisata terkenal. Untuk menilai hal tersebut digunakanlah metode anlisa SWOT (strength, weakness, opportunity, and threat). Kekuatan (strength) yang dimiliki Pantai Sanur Kaja adalah sistem yang dibuat dan diterapkan oleh desa untuk memperhatikan kebersihan yang sampai sekarang masih tetap terlakasana dengan baik dimana Pantai lainnya belum tentu memiliki ketetapan untuk menjaga kualitas kebersihan dari pantai itu sendiri. Kelemahan (weakness) yang ditemukan adalah rendahnya kesadaran wisatawan khususnya wisatawan lokal dalam pentingnya menjaga kebersihan di daya tarik wisata Pantai Sanur Kaja. Kesempatan (opportunity) yang dimiliki oleh Pantai Sanur Kaja diantaranya letaknya yang strategis, ketersediaan ruang yang cukup untuk menata sarana-prasarana pendukung, adanya kesempatan bagi masyarakat untuk terlibat dalam pengawasan, dan retribusi pengelola sarana tambahan kedalam kas anggaran desa untuk pengadaan tenaga kebersihan. Namun tak terlepas dari ancaman (threat) yang ada yakni pesaing dari daya tarik wisata yang cukup banyak di Bali dan jika tidak dapat memberikan kualitas kebersihan dan kenyaman yang memadai maka para wisatawan akan beralih ke tempat lain.

Keterbatasan dalam penelitian yang dihadapi yakni dalam proses pengumpulan 100 survei kuisioner yang dilakukan selama 3 minggu oleh karena keterbatasan tenaga pengumpulan data oleh penulis sendiri. Cuaca buruk, sibuknya perangkat desa, dan keterbatasan tempat penelitian yang hanya diperbolehkan di tempat umum, pada akhirnya dapat dilalui dengan baik.

Dari hasil yang diperoleh melalui survei 100 wisatawan domestik dan internasional hasil menunjukan penilaian wisatawan internasional hampir sama dengan wisatawan domestik. Sarana umum dan sarana tambahan sebagian besar sudah dianggap cukup bersih oleh wisatawan yang disurvei. Namun sebagian besar wisatawan domestik masih menganggap fasilitas tempat sampah masih kurang dengan beberapa alasan diantaraya; tempat sampah yang tersedia tidak dapat menampung banyaknya sampah oleh wisatawan, jauhnya letak tempat sampah. Namun sebaliknya sebagian besar wisatawan internasional merasa ketersediaan tempat sampah sudah cukup akan tetapi beberapa menyayangkan masih adanya wisatawan dan orang-orang yang membuang sampah meskipun telah disediakan tempat sampah. Secara keseluruhan diimbangi dengan 
keindahan alamnya, kebersihan Pantai Sanur Kaja sudah dianggap cukup

\section{KESIMPULAN}

Pengelolaan sarana umum, sarana tambahan, tempat sampah, dan kebersihan Pantai secara keseluruhan akan membuat daya tarik wisata Pantai Sanur Kaja makin diminati wisatawan. Dari hasil penelitian ini secara keseluruhan para wisatawan domestik maupun internasional mengganggap kualitas kebersihan Pantai Sanur Kaja sudah tergolong cukup. Namun untuk kedepannya masih banyak yang harus dilakukan baik oleh masyarakat, pengelola, dan kesadaran wisatawan untuk menjaga dan membuat kualitas kebersihan Pantai Sanur Kaja lebih baik dari sebelumnya. Pengamatan langsung serta wawancara menegaskan pentingnya kebersihan pada suatu daya tarik wisata dan disimpulkan bahwa semua yang ada dan mengunjungi daerah wisata tersebut memiliki tanggung jawab tersendiri untuk mempertahankan kualitas kebersihan yang ada. Karena suatu tujuan wisata yang nyaman dimulai dari kualitas kebersihan yang baik.

\section{DAFTAR PUSTAKA}

Indonesian Ministry of Tourism and Creative Energy 2013. Sanur Beach: Watch the Sunrise From Below The Ocean. Ministry of Tourism Indonesia. http://www.indonesia.travel/en/destination /524/sanur-beach-watch-the-sun-rise-from-belowthe-horizon.[Acessed: 12 October 2013]

Pemerintah Kota Denpasar. 2013. Wilayah Kota Denpasar Selatan: Sanur. Pemerintah Kota Denpasar. http//www.bali.go.id/sanur_index.php. [Diakses: 13 Juni 2013]

Gautama IGA. Evaluasi Perkembangan Wisata Bahari di Pantai Sanur. Thesis Faklutas Pariwisata Universitas Udayana. 2011;

Dwipayanti P. 2008. Ketersediaan dan Pengelolaan Toilet di Tempat Wisata Pulau Bali. Makalah Seminar. Denpasat, Bali. Fakultas Kedokteran IKM, Universitas Udayana.

Kamasan W. The Prevalence of international adult travellers with recommended vaccine visiting Sanur. e-journal Faculty of Medicine, Udayana University. 